\title{
TOURIST DIRECTION OF CROSS-BORDER REGIONS DEVELOPMENT OF RUSSIA
}

\author{
Svetlana Victorovna Stepanova* \\ Institute of Economics of the Karelian Research Centre of the Russian Academy of Sciences, \\ Russia, Republic of Karelia \\ Vladimir Ivanovich Shulepov \\ Volga State University of Technology, Russia, Republic of Mari El, Yoshkar-Ola
}

\begin{abstract}
The increasing role of the tourist scope of activity in the economy of many countries and regions of the world rationalized the proposed topic of the research. The development of tourism in the crossborder regions of Russia is regarded as a promising/priority trend for the regional development. At the turn of $20^{\text {th }}-21^{\text {st }}$ centuries in age of globalization and integration processes in the international community the socio-economic changes in Russia have brought dramatic changes in the logic of the development of Russian regions, and have formed the basis of the intensification of development and utilization of the capacity of cross-border areas, including tourist and recreational development. The purpose of the research is to describe the results of the study of qualitative changes in the development of tourism in the cross-border regions of Russia. The article represents the methodological approach to the assessment of the development of tourism and recreation activities of cross-border regions of Russia, as well as it substantiates the long-term benefits of tourism and recreation development. The study is carried out with a comparative analysis of the development of tourism indicators in Russia and thirty-seven regions, which have the land state border, for the period of 2002-2014 yrs. The holistic character of the research is contingent upon taking into account the reasonable and sufficient key indicators of tourist scope of activity: the tourism and hotel services, the dynamics of tourist mobility, and the development of tourist infra-structure. The article has theoretical and practical relevance for the scientists, researching the problems of development of tourism in the cross-border belt of Russia, for the authorities of the cross-border regions, as well as for the representatives of tourism industry.
\end{abstract}

Key words: Cross-border region, Russia, The development of tourism, Tourism infrastructure, Tourism services, Hotel services, Tourist flow

\section{INTRODUCTION}

At the turn of $20^{\text {th }}-21^{\text {st }}$ centuries in age of globalization and integration processes in the international community the socio-economic changes in Russia have brought dramatic changes in the logic of the development of Russian regions, and have formed the basis of the intensification of development and utilization of the capacity of cross-border areas, including tourist and recreational development. The de-velopment of tourism in the cross-border regions of Russia is turning into a promising/priority trend for the regional development, contributing to the improvement of employment and self-employment of the local population, the flow of income to the budget at all levels, the preservation and restoration of cultural, historical and natural heritage of territories.

The specific character of the economic and geographical location, the unique tourist and recreational potential of cross-border regions, which reveals the opportunities for developing different types of tourism, and changing the perception of tourism as a scope of economic activity at the level of govern-ment, business and society - all these contributed into creating a favorable basis for the development of tourism vector of development for the cross-border constituent entities of the Russian Federation. Having acknowledged the tourism as a promising/priority trend of development of cross-border regions of Russia, we 
see it fit-for-purpose to identify common trends, specific features and benefits of tourism development to improve the efficiency of the regional tourism industry and the regional economy as a whole.

\section{LITERATURE REVIEW}

Closer attention to the tourism and recreational development of cross-border areas leads to increase in the number of research works of the Russian scholars, revealing the current state, the specific features and efficiency of the tourism industry in the cross-border regions of Russia. One should specify that that during the Soviet period of the state development the specific economic and geographical loca-tion of cross-border regions (especially those bordering upon the capitalist countries), as well as the not accepting tourism as an area of economic activity at the level of state, business and society, did not allow for the use of existing unique tourist and recreational potential of territories.

In the current context, the cross-border regions were given an opportunity to develop tourist and recreational scope of activity and to stir it up based on the social and economic development. The profes-sor of Lomonosov Moscow State University A.Yu. Alexandrova has put it in the following way: 'the cross-border areas ... have the potential for development ... but ... their functionality is reduced to a mini-mum, so that it is important for the cross-border territories to acquire tourism functions' [02]. Opportuni-ties and prospects of development of cross-border cooperation in the tourism sector, tailoring cross-border tourist destinations, while taking into account the best practices of cross-border international destinations, may determine the relative advantage of cross-border areas in the development of tourism industry in comparison to the hinterland territories of the state.

The growing impact of tourism on the socio-economic development of cross-border regions rationalizes the problems of research on the processes of mobility, tourism and the migration of citizens in the world community $[06,08,11,14$, 18-21]. Over the last years, the number of works by Russian scholars, presenting numerous aspects of cooperation between the cross-border regions of Russia with the neigh-boring countries in the context of the tourist mobility, is increasing. $[10,15]$. Given the key role of the develop- ment of tourism infrastructure in the functioning of the regional tourism industry, the scholars have accumulated considerable research capacity for understanding and comprehending the current state, the specific features and problems of development of tourist infrastructure in some cross-border regions of Russia [05, 09, 13, and 17]. The studies of issues of development of tourist and recreational complex of cross-border regions $[16,17]$, the issues of cross-border and trans-border cooperation in the field of tour-ism are of special interest [03, 07, 09, 12, 22]. However, the accumulated research capacity, due to the re-gional nature of the existing developments, does not allow to fully modeling the comprehensive insight into general trends and specific features of the development of tourism in the cross-border belt of Russia.

\section{PROBLEM STATEMENT AND METHODOLOGY}

The paper proposes the approach, which allows validating the qualitative changes in the develop-ment of tourism, identifying common trends and patterns of tourism and recreation activities in the cross-border regions of Russia. The study is carried out with a comparative analysis of the development of tour-ism indicators in Russia and thirty-seven regions, which have the land state border, for the period of 2002-2014. The holistic character of the research is contingent upon taking into account the reasonable and sufficient key indicators of tourist scope of activity: the tourism and hotel services, the dynamics of tourist mobility, and the development of tourist infrastructure.

The study utilizes the analysis of the conceptual and terminological system, method of analogies, a group of statistical methods, including the method of regression analysis and a method of analyzing the dynamics of the series.

\section{RESULTS AND DISCUSSION}

The methodological approach to the assessment of the development of the international tourism in the cross-border regions of Russia

At the turn of $20^{\text {th }}-21^{\text {st }}$ centuries in age of globalization and integration processes in the international community the socio-economic changes in Russia have impacted the volumes and destinations of inbound and outbound tourist flows; the 
development of international tourism has undergone significant changes, both at the state level and at the level of an individual.

The dynamics of inbound and outbound tourist flows on the territory of the thirty-seven crossborder regions for the period of 2005-2014. correlates with the national trends. On the one hand, a steady increase in the number of Russian citizens, who went on tours, characterizes the welfare of the local population, living on the territory of the cross-border regions of the Russian Federation, and can be regarded as a positive trend. On the other hand, the dominant part of the tours purchased are tours abroad with a slight increase in the number of domestic tours purchased by the Russians. However, the external factors (such as Ruble's exchange rate, the threat of terrorist attacks, etc.) can eventually have a signifi-cant impact on changing preferences in the choice of holiday destinations and on redistributing the tourist flow of the Russians. In addition, one can observe the competence improvement of a modern Russian tourist: an independent booking, tour purchasing, and other tourism and related services on the Internet, without any support by tourism organizations. Thus, there was a growth record for flight reservations across Russia (the most common domestic flights were booked online) in 2014. According to the online travel hypermarket DaTravel.com, the share of the Russians who planned their leisure activities by them-selves has increased to $32 \%$ in 2015 (2014 - 22\%, 2013 - 9\%). For instance, the Russian cross-border re-gions totally hosted third $(35.2 \%)$ of the international travellers arriving from far-abroad countries in 2014 . On the assumption of the indicators of hosting internation- al travellers (33\% out of $35.2 \%) 13$ cross-border regions bordering upon far-abroad countries can be characterized as the regions of the greatest tourist attraction.

The following regions are the leading regions in hosting the international travellers: the Republic of Karelia, the Primorsky Krai, the Amur Region, the Kaliningrad region and the Sakhalin region. The practice of a visa-free regime for foreign citizens, those who arrive in the territory of the Russian Federa-tion on Passenger Ferries for a period up to 72 hours for the tourist purposes, into the harbors of St. Pe-tersburg, Vladivostok, Vyborg, Kaliningrad, Korsakov, Novorossiysk and Sochi [01] breaks new ground of generating tourist flows from abroad, and building the socioeconomic benefit to the regional develop-ment of the cross-border regions of Russia.

The cross-border tourism, including tourist mutual migration between the territories of neighboring countries [15], acquires particular importance in the development of international tourism in the cross-border regions. Thus, in the case when the volume of the flow of inbound tourists from the neighboring state to the territory of the Russian Federation is insignificant in the total inbound tourist flow, it still can be tangible to the crossborder region. Moreover, the incomes earned in the region and the socio-economic benefits arising from the development of this type of economic activity, could be significant at the regional level [15]. For example, in some cross-border regions there is a stable development dependency of the international inbound tourism on tourist preferences of a certain far-abroad state (Table 1).

Table 1: The dynamics of the share of international travellers in the total inbound tourist flow to the region for the period of 2005-2014

\begin{tabular}{|c|c|c|c|c|c|c|}
\hline No & region & state & 2005 & 2008 & 2011 & 2014 \\
\hline 1 & the Republic of Karelia & Finland & 90.6 & 99.1 & 99.1 & 98.3 \\
\hline 2 & the Kaliningrad Region & Germany & 79.3 & 82.7 & 65.5 & 51 \\
\hline 3 & the Primorski Krai & P.R.China & 89.8 & 85.4 & 82.8 & 83.4 \\
\hline 4 & The Amur Region & P.R.China & 99.9 & 99.7 & 99.9 & 99.9 \\
\hline 5 & the Jewish Autonomous Region & P.R.China & 100 & 100 & 100 & 100 \\
\hline 6 & the Khabarovsk Krai & Japan & 55.9 & 78.3 & 91.2 & 73 \\
\hline
\end{tabular}

Note: hereinafter, the calculation is based on the sources 
The most dependent on the preferences of Chinese tourists are the Jewish Autonomous Region, where the average value of the index for the period of $2005-2014 \mathrm{yrs}$. is $100 \%$, the Amur region $(99.9 \%$, the minimum value of $99.7 \%)$ and the Primorski Krai (83.8\%; 49.4\%). Similarly, the Republic of Karelia is dependent on Finland $(98.7 \% ; 90.6 \%)$ the Khabarovsk Krai - on Japan $(68.1 \% ; 52.4 \%)$ and the Kali-ningrad Region on Germany $(71.5 \%$; $48.3 \%)$. The results show, on the one hand, the advantage of the cross-border regions as attractive tourist areas over the other regions of the Russian Federation, on the other hand, a certain degree of dependency on the preferences of international travellers is fraught with certain risks. [15]

\section{The methodological approach to the assessment of the development of tourism and hotel services}

During the period of 1997-2014 there have been a steady growth in the tourist services pro-vided in the Russian Federation, and the third-ranked tourist services (in average $28.6 \%$ ) are in the cross-border regions of Russia (Figure 1).

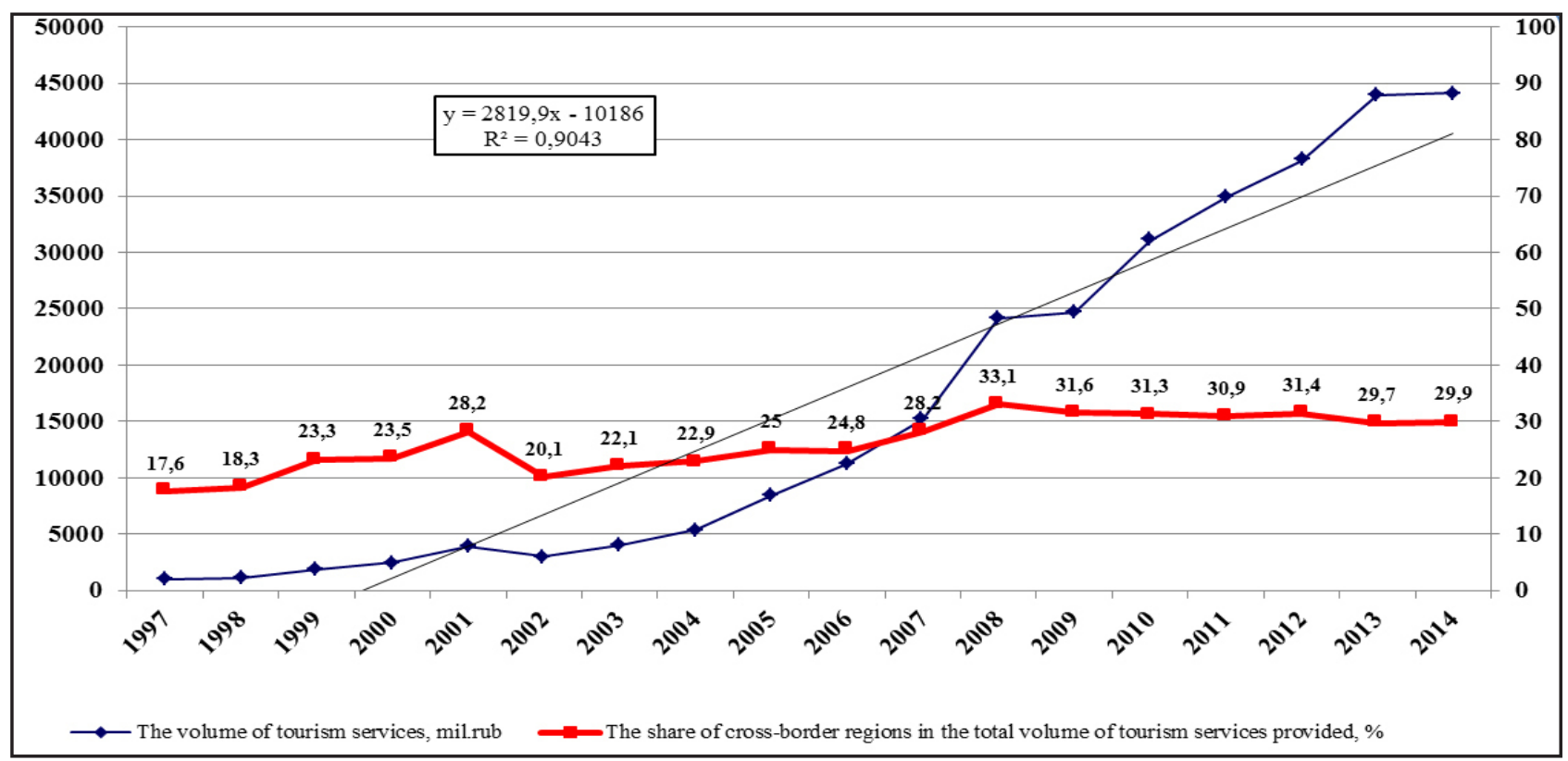

Figure 1: Dynamics of the volume of tourism services in the cross-border regions of Russia for the period of 1993-2014

Changes in the approaches to the management of tourism development, closer attention to the de-velopment of domestic and international tourism at the federal and regional levels of authority realized in a sustainable growth dynamics of the main indicators. Thus, the growth of tourism services provided in the cross-border regions was 14.5 times for the period of 2002-2014, the growth of hotel services - 9.6 times. It is worth emphasizing that the development of hotel services largely determines the develop-ment of the tourism industry, but not only the development of the excursion part, considering the multi-plier effect that this scope of economic activity produces in the regions.

For this purpose, building the tourism infrastructure that meets international standards in the cross-border regions is regarded as the basis for the development of tourism industry and the provision of a wide range of competitive tourism services, contributing to the attraction of tourist flows in terms of inter-regional and international competition for tourists and investment. On the contrary, the constraints, determined by the level of the tourism infrastructure development (lack of the development, deterioration, a significant territorial differentiation, etc.) prevent from unlocking the tourism potential of the area, eventually reducing the tourist capacity of the region. [16] Juxtaposing the average performance of the tourism infrastructure development in the cross-border regions of Russia and in Russia as a whole in 2014 (for more details see [16]) rationalizes a certain dependency of the development of tourism infrastructure in the region on the spatial position of the latter to the state border. This was 
largely determined by the specific character of the development of cross-border areas, taking into account the function that the state border has performed for a long period in the history of the state. However, with the changes in the perception of tourism, and acknowledging this sphere of activity as the (new) promising and / or priority trend of socio-economic development of regions at the level of government, business and society, we can observe the process of intensive development of tourism infrastructure, especially the accommodation infrastructure [16].

Thus, the influence of the state border on the development of accommodation infrastructure is vis-ible in the advanced dynamics of growth rates in cross-border regions, compared with the average Russian indicators: the increase in the number of hotels for the period of 2002-2014. has been 2.8 times and 2.35 times; increase in the number of room in the hotels has been 2.77 times and 2.56 times, respectively. It is worth emphasizing that the priority rates of accommodation infrastructure for the research period has been achieved through intensive development of the number of rooms in cross-border regions, neighboring with far-abroad countries (almost 2.2 times increase). [16]

During the period of 2002-2014 there have been a steady trend of growth rate of availability of accommodation infrastructure in cross-border regions (rooms in hotels and similar accommodation facilities, per 1 thou. pers.), which indicates the potential and prospects of development of tourism indus-try in these regions (Table 2).

Table 2: Potential and prospects od development of tourism industry

\begin{tabular}{|c|c|c|c|c|}
\hline $\begin{array}{c}\text { cross-border } \\
\text { region }\end{array}$ & 2002 & 2010 & 2012 & 2014 \\
\hline $\begin{array}{c}\text { an average of } \\
37 \text { cross-border } \\
\text { regions }\end{array}$ & 2.6 & 5.2 & 5.5 & 7.7 \\
\hline
\end{tabular}

This is particularly evident in the regions of Russia, bordering upon the far abroad countries, where the dominant barrier function of the state border in the Soviet period of history (with the capitalist countries) restricted the transfer of goods, services, people mobility, and the possibility of economic de-velopment of the territories.

\section{CONCLUSION}

The results substantiate the qualitative changes in the development of tourism in the cross-border regions of Russia. The analysis of indicators of tourism development in the cross-border regions elicits the high tourist attractiveness for international travellers, as well as the potential and prospects of these regions for the development of tourism and recreation activities. Tailoring cross-border tourist destinations seems to be one of the tools to increase the efficiency of the functioning of tourism, to strengthen the competitiveness of the territory on the market of tourist services, to stimulate social and economic development of cross-border regions. Moreover, the tourist vector of development contributes to the preservation and restoration of natural, cultural and economic potential of the cross-border regions of Russia. However, there are a number of systemic problems of the functioning of the tourism industry, that are common for the majority of the Russian regions and typical of crossborder Russian constituent enti-ties; so, these problems can be solved by a comprehensive approach with consolidated efforts of government, business and society. The level and the quality of functioning of tourism and transport infrastruc-ture [04, 16] are crucial while developing the tourism industry, and the possibility of using the tourism po-tential of the region (including the transport accessibility). Further research assumes the design of a set of incentives and tools to support the tourist development of crossborder regions; it will also focus on the development measures for regional economic policy in the tourism domain, aiming at increasing the use of tourist and recreational potential of the territory (without damaging the environment), and will focus on improving the quality of life of the Russian population in the context of leisure and recreation.

\section{REFERENCES}

1) Abramova, T. 2011, Problemy I perspektivy turistskoj industrii v Rossii [Problems and prospects of tourism industry in Russia], Vestnik Instituta economiki RAN [Bulletin of the Institute of Economics], no. 4, P. 193-208.

2) Aleksandrova A.Yu. 2012 Politiko-administrativnie granitsi: ot bariera $\mathrm{k}$ turistskomu resursu [Polical-administrative borders: from a barrier to tourist resource], Vestnik Moskovskogo Un-viersiteta [Bulletin of Moscow University], no. 3. - Seriya 5 [Edition 5]. 
3) Geografiya [Geog-raphy]. - P. 15-20.

4) Aleksandrova, A. Yu., Stupina, O. S. 2014. Turistskoe regionovedenie: Vliyanie regionalnoy integracii na mirovoy turistskiy rynok [Tourist regional studies: the impact of regional integra-tion on the world tourist market], Moscow, p. 176.

5) Bucher S. Competitiveness of the Russian Federation in the Global Tourism Market // Econo-my of region, 2016. - T. 12. - no 1. - P. 240-250. DOI 10.17059/2016-1-18

6) Korneevets V.S., Semenova L.V. Klasterniy podkhod $v$ razvitii turizma Kalinindradskoi oblasti [The cluster approach in tourism development in the Kaliningrad region], Vestnik Baltiiskogo federalnogo universiteta im.l.Kanta [Bulletin of Immanuel Kant Baltic Federal University], 2013, no. 9. P. 153-159.

7) Kovács I., Nagy G. (2013). Tourism in peripheric regions - the possibilities of thematic routes // Analele UniversităŃii din Oradea - Seria Geografie, 2. pp. 220-228

8) Kretinin G., Ostashkova T. Maloe prigranichnoe dvizhenie kak predmet istoricheskogo issle-dovaniya I sovremennost [Minor border traffic as the subject of historical research and today], Acta humanitarica universitatis Saulensis. 2012. Vol. 14. P. 314-321.

9) Leitão N. C., Shahbaz M. Migration and Tourism Demand // Theoretical and Applied Economics. 2012. Vol. XIX. № 2 (567). P. 39-48.

10) Mezhevich N. M., Zhuk N.P. Cross-border specialization of interregional interaction: applying new assessment methods // Baltijskij region, 2013. no1. P. 38-52. doi: 10.5922/2074-9848-2013-1-3

11) Miroshnichenko O.V., Ponkratova L.A.. Mezhdunarodnie turistskie migratsii kak factor integrationnikh protsesov mezhdu regionami Kitaiya i Rossii [International tourist migrations as a factor of integrational processes between regions of China and Russia], Upravlenie ekonomichskimi sistemami [Managing Economic Systems: Electronic scientific journal]. 2011.no. 32.

12) Pirozhnik I.I. Toristskie migratsii $v$ transgranichnom regione kak factor aktivizatsii ekonomicheskogo sotrudnichestva (na primere Belorussko-Polskogo pogranichiya) [Tourist migrations in trans-border region as a factor of economic development: a case of BelorussianPolish borderzone], Problemi bezopasnosti rossiskogo obschestva [Problems of Russian society security] 2015 , no. 2. P. 141-150

13) Schielberg S. Cross-Border Cooperation between Kaliningrad Region, Lithuania and Poland: Obstacles and Possibilities // Baltijskij region, 2009. no 2. P. 129-135

14) Shulepov V.I., Stepanova S.V. Development of tourism and recreation activities in crossborder regions of Northwest Russia: general trends and features. Indian Journal of Science and Technology, August, $2016 \mathrm{Vol} 9$ (issur 29) doi: 10.17485/ijst/2016/v9i29/88684

15) Spiriajevas E. (2008) The impact of tourism factor for development of the south-east Baltic coastal - border regions // GeoJournal of TourIsm and Geosites, No. 2, vol. 2, pp.118-128

16) Stepanova S.V (2014) .Cross-border tourism in the Russian Northwest: general trends and features of development, The Baltic region, no 3 (21), 109-121 DOI - 10.5922/2074-9848-2014-3-10

17) Stepanova S.V. General Trends and Features of Tourism Infrastructure Development in Rus-sia's Regions // Moscow University Economics Bulletin, 2016. no 3. P. 68-84

18) Tappaskhanova E. ., Mustafaeva Z. A., Tokmakova R. A., Kudasheva M. Z. Region Tourist and Recreation Complex Development // Economy of region, 2015. № 2 (42). C. 208219. doi $10.17059 / 2015-2-17$

19) Timothy, D.J. Political boundaries and tourism: border as tourist attractions. // Tourism management. 1995. Vol.16. No. 7. P. 525—532.

20) Timothy, D.J., Guia J., Berthet N. Tourism as a catalyst for changing boundaries and territorial sovereignty at an intemational border // Current issues in tourism. 2014. Vol. 17. No 1. P. 21-27.

21) Vodeb K. (2010) Cross-border regions as potential tourist destinations along the Slovene Groatian frontier // Tourism and hospitality management, Vol. 16. No 2. pp. 219-228.

22) Więckowski M. (2010). Tourism development in the borderlands of Poland // Geographia Polonica, 93.2 pp. $67-81$

23) Zaitseva N.A., Kropinova E.G. 2016, Problems and Prospects of Cross-Border Cooperation in Tourism between Russia and Europe // Baltijskij region, Vol. 8, no. 3, p. 133-146. doi: 10.5922/2074-9848-2016-3-8.

Paper sent to revision: 26.07.2017.

Paper ready for publication: 03.08.2017. 